\title{
COX-2 selective inhibition reverses the trophic properties of gastrin in colorectal cancer
}

\author{
M Yao', DH Song', B Rana' and MM Wolfe*,' \\ 'Section of Gastroenterology, Boston University School of Medicine and Boston Medical Center, 605 Albany Street, Room 504, Boston, Massachusetts, \\ MA 02118, USA
}

Gastrin is a gastrointestinal peptide that possesses potent trophic properties on both normal and neoplastic cells of gastrointestinal origin. Previous studies have indicated that chronic hypergastrinaemia increases the risk of colorectal cancer and cancer growth and that interruption of the effects of gastrin could be a potential target in the treatment of colorectal cancer. Here we demonstrate that gastrin leads to a dose-dependent increase in colon cancer cell proliferation and tumour growth in vitro and in vivo, and that this increment is progressively reversed by pretreatment with the cyclo-oxygenase-2 inhibitor NS-398. Gastrin was able to induce cyclo-oxygenase-2 protein expression, as well as the synthesis of prostaglandin $E_{2}$, the major product of cyclo-oxygenase. Moreover, gastrin leads to approximately a two-fold induction of cyclo-oxygenase-2 promoter activity in transiently transfected cells. The results of these studies demonstrate that cyclo-oxygenase- 2 appears to represent one of the downstream targets of gastrin and that selective cyclo-oxygenase-2 inhibition is capable of reversing the trophic properties of gastrin and presumably might prevent the growth of colorectal cancer induced by hypergastrinaemia. British Journal of Cancer (2002) 87, 574-579. doi:I0.1038/sj.bjc.6600495 www.bjcancer.com

(c) 2002 Cancer Research UK

Keywords: gastrin; cyclo-oxygenase; colorectal cancer; trophic properities

The polypeptide hormone gastrin was identified nearly 100 years ago, and its role in the physiology of gastric acid secretion is well-established (Modlin et al, 1997). Another biological property attributed to gastrin is its trophic effect on gastrointestinal (GI) mucosa, including its role in the pathogenesis of GI carcinogenesis (Koh et al, 1999; Stepan et al, 1999; Koh and Chen, 2000). Previous epidemiological studies have indicated that chronic hypergastrinaemia constitutes a risk factor for the development of colorectal cancer (Hakanson et al, 1986; Sundler et al, 1986; Wolfe, 1992; Lamberts et al, 1999; Singh et al, 2000; Watson and Smith, 2001). Significant hypergastrinaemia occurs in association with a number of clinical conditions, including pernicious anaemia and Zollinger-Ellison syndrome and following the development of potent acid suppression in response to the administration of proton pump inhibitors (Klingensmith et al, 1999). The increased incidence of colorectal cancer in hypergastrinaemic patients appears to occur as a result of an increased rate of proliferation of normal colonic epithelium, thus increasing the chance of sporadic mutations. Hypergastrinaemia may also enhance the proliferation and progression of colorectal adenomas (Thorburn et al, 1998; Watson and Smith, 2001).

Epidemiological studies have demonstrated a $40-50 \%$ reduction in mortality from colorectal cancer in individuals taking nonsteroidal anti-inflammatory drugs (NSAIDs), which appears to reduce the risk of colorectal cancer (CRC) by inhibiting cyclo-oxygenase (COX), a key enzyme involved in the metabolic conversion of arachidonic acid to prostaglandins (Giovannucci et al, 1994; Giardiello et al, 1995). Numerous studies have shown that the expression of COX-2, one of the two isoforms of COX, is increased

*Correspondence: MM Wolfe; E-mail: michael.wolfe@bmc.org Received 8 March 2002; revised 16 May 2002; accepted 16 May 2002 significantly in colonic neoplasms compared with normal colonic mucosa, and that COX-2 plays an integral role in colon cancer tumorigenesis and proliferation (Sheng et al, 1997; Barnes et al, 1998; Barnes and Lee, 1998; Sawaoka et al, 1998; Tsujii et al, 1998). However, the cellular and molecular mechanisms governing any possible relationship between gastrin and COX during GI tumour growth have not been elucidated. The purpose of this study was to examine whether COX-2 inhibition is able to reverse the trophic properities of gastrin in CRC.

\section{MATERIALS AND METHODS}

\section{Cell culture}

MC-26 cells, a transplantable mouse colon cancer cell line that possesses both COX-2 and functional gastrin receptors (Singh et al, 1986), were obtained from Dr KK Tanabe (Boston, MA, USA). MC-26 cells were maintained in Dulbecco's Modified Eagle Media (DMEM; Life Technologies, Inc, Gaithersburg, MD, USA) supplemented with $10 \%$ fetal calf serum and antibiotics (100 $\mathrm{U} \mathrm{ml}^{-1}$ penicillin and $100 \mu \mathrm{g} \mathrm{ml}^{-1}$ streptomycin) at $37^{\circ} \mathrm{C}$ in a humidified atmosphere of $95 \%$ air per $5 \% \mathrm{CO}_{2}$.

\section{Proliferation studies}

DNA synthesis was estimated by the measurement of $\left[{ }^{3} \mathrm{H}\right]$ thymidine incorporation into cellular DNA. Cells $\left(100000 \mathrm{ml}^{-1}\right)$ were seeded onto 12- or 24-well plates and allowed to attach overnight, after which they were incubated in serum-free medium for another $24 \mathrm{~h}$. This incubation was followed by treatment with different concentrations of gastrin-17 (G-17; Peninsula Laboratories, San Carlos, CA, USA) in the presence or absence of the specific COX-2 inhibitor, NS-398 (Cayman Chemical, Ann Arbor, 
MI, USA). NS-398 and gastrin-17 were dissolved in DMSO and $30 \mathrm{mM} \mathrm{NH} \mathrm{HCO}_{3}$, respectively, as stock solutions. One $\mu \mathrm{Ci} \mathrm{ml} \mathrm{H}^{-1}$ of $\left[{ }^{3} \mathrm{H}\right]$ thymidine (New England Nuclear Products, Boston, MA, USA) was added and allowed to incorporate for $6 \mathrm{~h}$ at $37^{\circ} \mathrm{C}$. Cells were washed with cold phosphate buffered saline (PBS) three times. Cold $10 \%$ trichloracetate (TCA) was added to cells and maintained at $4{ }^{\circ} \mathrm{C} 30 \mathrm{~min}$, after which cells were washed again with cold PBS three times and lysed in $0.1 \mathrm{~N} \mathrm{NaOH}$ per $10 \%$ SDS. Radioactivity was counted in a liquid scintillation counter, and data were expressed as percentage of control \pm standard error (s.e.) of several experiments.

\section{Mouse colorectal cancer model}

Six- to ten-week old male BALB/C mice were obtained from Taconic (Germantown, NY, USA). MC-26 cells were harvested from subconflent cultures using trypsin-EDTA, followed by centrifugation at $300 \mathrm{G}$ for $15 \mathrm{~min}$ at room temperature. Cells were then resuspended in serum-free DMEM or Hank's Balanced Salt Solution (Life Technologies, Inc, Gaithersburg, MD, USA), and the cell number was adjusted to a final concentration of 100000 cells per ml. Using a 27-gauge needle and a $1 \mathrm{ml}$ syringe, $100 \mu \mathrm{l}$ of tumour cell suspension was injected subcutaneously into the flanks of mice. All animal studies were conducted using a protocol approved by the Animal Care and Use Committee at Boston University Medical Center and in accordance with UKCCCR Guidelines (Workman et al, 1998).

\section{Animal study procedure}

NS-398, dissolved in DMSO, was administered by oral gavage once daily. G-17 was dissolved in $0.9 \% \mathrm{NaCl}$ and was administrated using an implanted Alzet ${ }^{\circledR}$ osmotic pump (Alza corporation, Palo Alto, CA, USA). For osmotic pump insertion, animals were anaesthetised using intraperitoneal pentobarbital $\left(65 \mathrm{mg} \mathrm{kg}^{-1}\right)$ injection. An incision $\sim 0.8 \mathrm{~cm}$ in length was made, and the osmotic pump was implanted subcutaneously. After tumour cell injection, mice were randomly divided into four groups (10 animals per group) on day 0 , followed by treatment with different test reagents:

Group 1 (control group): Infusion of $0.9 \% \mathrm{NaCl}$ by osmotic pump and DMSO (vehicle) $0.1 \mathrm{ml}$ by gavage;

Group 2: Infusion of G-17 $10 \mathrm{nmol} \mathrm{kg}{ }^{-1} \mathrm{~h}^{-1}$ by osmotic pump and DMSO $0.1 \mathrm{ml}$ by gavage;

Group 3: Infusion of G-17 $10 \mathrm{nmol} \mathrm{kg}{ }^{-1} \mathrm{~h}^{-1}$ by osmotic pump along with NS-398 $1 \mathrm{mg} \mathrm{kg}^{-1}$ body weight by gavage; and

Group 4: Infusion of G-17 $10 \mathrm{nmol} \mathrm{kg}{ }^{-1} \mathrm{~h}^{-1}$ by osmotic pump along with NS-398 $10 \mathrm{mg} \mathrm{kg}^{-1}$ body weight by gavage.

Subcutaneous tumour size was determined after day 7 by measuring the longest and shortest diameters of the tumour at 2-3 day intervals. Tumour volume $\left(\mathrm{mm}^{3}\right)$ was calculated using the standard formula: tumour volume $=(\text { shortest diameter })^{2} \times($ longest diameter $) \times 0.5$. After sacrificing the mice on day 18 , tumours were excised and weighed and measured. Tumour tissue was flash frozen in liquid nitrogen and stored at $-70^{\circ} \mathrm{C}$, and a portion of the tissue was fixed with $10 \%$ formalin for histological examination.

\section{Prostaglandin $\mathrm{E}_{2}$ assay}

MC-26 cells $\left(100000 \mathrm{ml}^{-1}\right)$ were seeded onto six-well plates and allowed to attach overnight. Cells were then cultured in serum-free medium for another $24 \mathrm{~h}$, followed by treatment with $20 \mathrm{nM}$ of G17. To evaluate the activity of COX, prostaglandin $\mathrm{E}_{2}\left(\mathrm{PGE}_{2}\right)$, the major metabolite of arachidonic acid metabolism, was measured by an enzyme immunoassay (EIA) kit (Cayman Chemical, Ann Arbor, MI, USA) in culture media maintained at $20^{\circ} \mathrm{C}$ using the protocol provided by manufacturer. Measurements were made in triplicate in three separate experiments.

\section{Transfection and reporter gene assays}

To examine transcriptional regulation of the COX-2 promoter by gastrin, MC-26 cells were transiently transfected with 742-kb COX-2 promotor (kindly provided by Dr H Herschman, UCLA) or control plasmid pGL3-Luc (Promega, Madsion, WI, USA) in the presence of G-17 using Lipofectamine ${ }^{\mathrm{TM}}$ Reagent (Life Technologies, Inc, Gaithersburg, MD, USA). A $\beta$-galactosidaseexpressing plasimd was included in each transfection to monitor the transfection efficiency. For luciferase assay, transfected cells were washed twice with phosphate buffered saline (PBS, pH 7.4) and lysed in $200 \mu \mathrm{l}$ of lysis buffer following the manufacturer's instructions (BD PharMingen, San Diego, CA, USA). $\beta$-galactosidase activity in $50 \mu \mathrm{l}$ of the cell lysate was determined after 5$20 \mathrm{~min}$ incubation at $37^{\circ} \mathrm{C}$ with $2 \mathrm{mM}$ chlorophenol red $\beta$-galactopyranoside (Boehringer Mannheim, Indianapolis, IN, USA) in $20 \mathrm{mM} \mathrm{MgCl}, 0.1 \mathrm{mM} \mathrm{MnCl}, 45 \mathrm{mM}$ 2-mercaptoethanol, and $100 \mathrm{~mm} \mathrm{NaHPO}$, pH 8.0. The reaction was stopped by adding $500 \mu \mathrm{l}$ of $0.5 \mathrm{M}$ EDTA, $\mathrm{pH} 8.0$, and the absorbency at $570 \mathrm{~nm}$ measured using a spectrophotometer. With each experiment, luciferase activity was determined in duplicate and normalized to $\beta$ galactosidase activity for each dish.

\section{Western blot hybridization}

Mouse COX-2 and cyclin D1 monoclonal antibodies were purchased from $\mathrm{BD}$ transduction laboratories (Lexington, $\mathrm{KY}$, USA). To extract protein from cells, MC-26 cells cultured under different conditions were harvested and lysed in RIPA buffer (PBS, $1 \%$ NP-40, $0.5 \%$ sodium deoxycholate, $0.1 \%$ SDS, $100 \mathrm{ng} \mathrm{ml}^{-1}$ PMSF, $66 \mathrm{ng} \mathrm{ml}^{-1}$ aprotinin). To extract protein from tissues, $0.1 \mathrm{~g}$ of tumour tissue was placed in $2.0 \mathrm{ml}$ of cold RIPA buffer and homogenized for $1 \mathrm{~min}$ with Polytron-Aggregate (Kinmatica, Luzern, Switzerland). After removal of cell debris by centrifugation, total protein of cells or tissues was determined by BCA protein assay (Pierce chemical, Rockford, IL, USA). Protein was mixed with gel loading buffer ( $50 \mathrm{~mm}$ Tris $\mathrm{pH} 6.8,2 \%$ SDS, $10 \%$ glycerol, $2 \%$ 2-mercaptoethanol, $0.1 \%$ bromphenol blue) and heated for $10 \mathrm{~min}$ at $100^{\circ} \mathrm{C}$. Samples containing $20-40 \mu \mathrm{g}$ protein were loaded on a $10-12 \%$ SDS-PAGE gel and then electrophoretically transferred to a polyvinylidene difluoride membrane in transfer buffer (25 mM Tris, $190 \mathrm{mM}$ glycine, $20 \%$ methanol). The blots were blocked with $7 \%$ dry milk for $1 \mathrm{~h}$ at room temperature and incubated with the primary antibody overnight. They were then washed three times for $15 \mathrm{~min}$ each in Tris-buffered saline, containing $0.05 \%$ Tween-20. The blots were further incubated with the anti-mouse IgG antibody (Sigma) for $1 \mathrm{~h}$ at room temperature. After washing three times, blots were incubated with luminous ECL reagent (Pierce chemical, Rockford, IL, USA) for $10 \mathrm{~s}$ to $2 \mathrm{~min}$ and exposed to Kodak X-ray film. Protein bands were quantified by laser densitometry.

\section{Immunohistochemistry}

Proliferating cell nuclear antigen (PCNA) monoclonal antibodies were purchased from BD transduction laboratories (Lexington, KY, USA). Paraffin-embedded specimens were deparaffinized and incubated with PCNA antibody for $2 \mathrm{~h}$ at $37^{\circ} \mathrm{C}$. The specimens were then incubated with the secondary antibody, anti-mouse $\mathrm{IgG}$, for $1 \mathrm{~h}$ at $37^{\circ} \mathrm{C}$ and stained by the avidin-biotin peroxidase complex (ABC) method using the $\mathrm{ABC}$ staining system (Santa Cruz Biotech, Santa Cruz, CA, USA). They were visualized by 3,3-diaminobenzidine (DAB) staining and counterstaining with haematoxylin. To confirm the specificity of the mouse PCNA antibody, tonsil specimens was used as a positive control. The PCNA index was evaluated by counting the number of PCNA-positive staining cells out of a total of 500 tumour cells: PCNA index $=$ 
(number of PCNA-positive-staining cells per 500 cells counted) $\times 100 \%$.

\section{Statistical analysis}

One-way ANOVA was performed to compare $\left[{ }^{3} \mathrm{H}\right]$ thymidine incorporation, tumour volume and weight, PCNA index, and densitometric values of Western blot bands among the different animal groups, followed by Tukey's procedure for paired comparison. The two-tailed $t$-test was used to compare $\mathrm{PGE}_{2}$ levels in the different conditions. Statistical significance was assigned if $P<0.05$.

\section{RESULTS}

\section{Cell proliferation}

The addition of G-17 led to an increase in $\left[{ }^{3} \mathrm{H}\right]$ thymidine incorporation, with $\sim 40 \%$ increase detected using at a G-17 concentration of $20 \mathrm{nM}$. NS-398, a COX-2 selective inhibitor, decreased $\left[{ }^{3} \mathrm{H}\right]$ thymidine incorporation in a dose-dependent manner. When MC-26 cells were incubated in culture media containing both $20 \mathrm{nM} \mathrm{G}-17$ and $10 \mu \mathrm{M}$ NS-398, $\left[{ }^{3} \mathrm{H}\right]$ thymidine incorporation was $110.0 \%$ of control (Figure 1), indicating that the enhancement in cell proliferation induced by gastrin could be partially attenuated by COX-2 inhibition with NS-398.

\section{Tumour growth}

In animal studies, 6- to 10 -week old BALB/C mice were inoculated with MC-26 cells subcutaneously on day 0 . Figure 2 depicts the effects of G-17 and NS-398 on tumour volume and tumour weight at the end of the period of observation (day 18). Twenty per cent of G-17 treated mice died as a result of heavy tumour burden. Both tumour volume and weight in mice treated with G-17
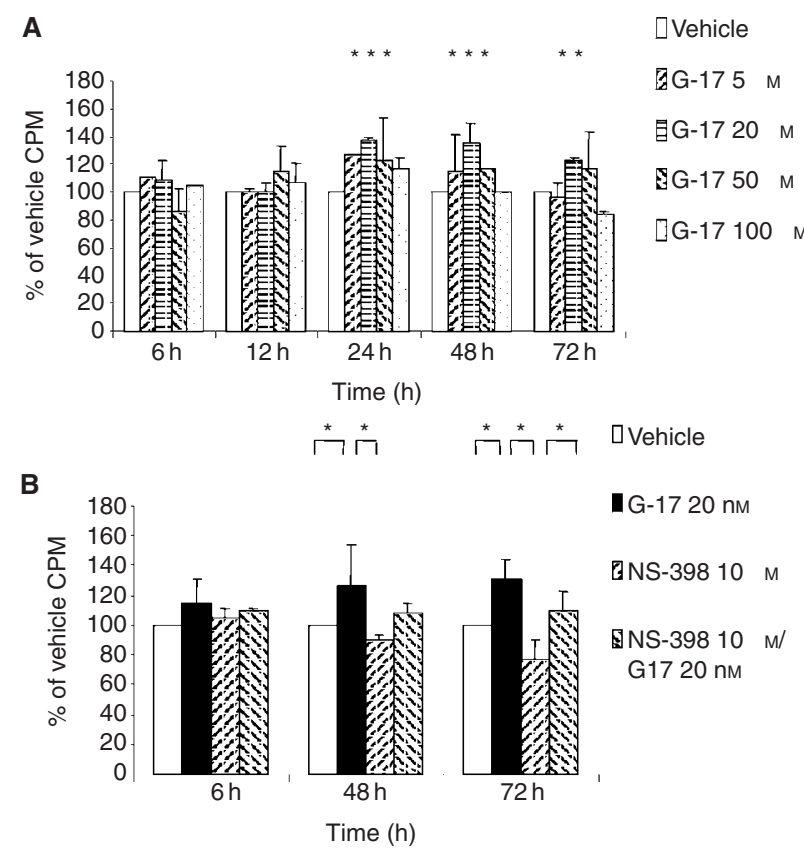

Figure I $\left[{ }^{3} \mathrm{H}\right]$ thymidine incorporation of colon cancer cells (MC-26) treated with gastrin-17 (G-17) in the absence or presence of the COX 2 selective inhibitor NS-398. DNA synthesis was estimated by $\left[{ }^{3} \mathrm{H}\right]$ thymidine incorporation into cellular DNA, as described in the Materials and Methods section, under various conditions: gastrin-17 (A) and the combination of G-17 and NS-398 (B). $* P<0.05$.
(10 $\mathrm{nmol} \mathrm{kg} \mathrm{kg}^{-1} \mathrm{~h}^{-1}$ ) were significantly greater than those in the control group (tumour volume 1761.8 $\pm 427.6 \mathrm{~mm}^{3}$ vs $1220.2 \pm 224.0 \mathrm{~mm}^{3}$, tumour weight $0.53 \pm 0.04 \mathrm{~g} v s 0.38 \pm 0.07 \mathrm{~g}$, $P<0.05)$. In contrast, no significant differences in tumour volume
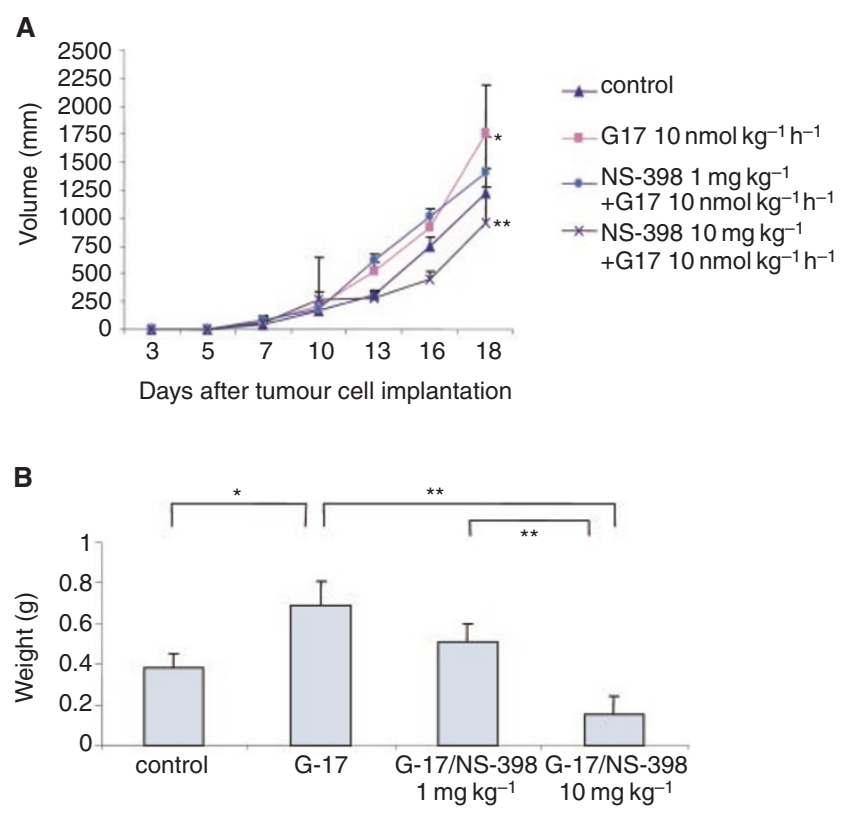

Figure 2 Effect of gastrin-I7 (G-17) orland the COX-2 selective inhibitor (NS-398) on colon cancer growth in vivo. MC-26 cells were injected subcutaneously in the flank of 6 to 10 -week old male BALB/c mice. Subcutaneous tumour size was determined from day 7 by measuring the longest and shortest diameter of the tumour at 2-3 days intervals. (A) Tumour volume $\left(\mathrm{mm}^{3}\right)$ was calculated by a standard formula: Volume $=$ (the shortest diameter $)^{2} \times($ the longest diameter $) \times 0.5$. (B) Tumour weight was measured on day 18 after tumour was removed from sacrificed mice. $* P<0.05$. $* * P<0.01$.

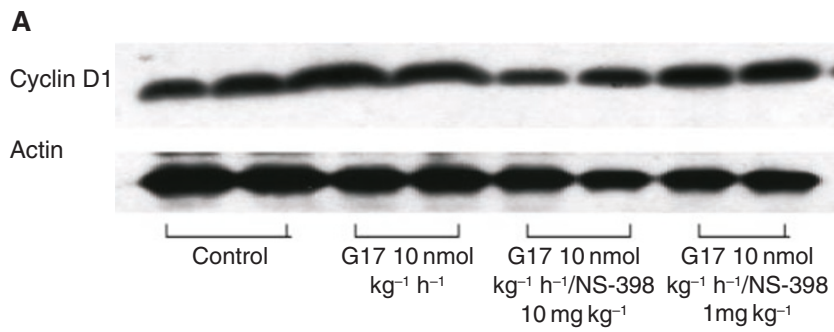

B

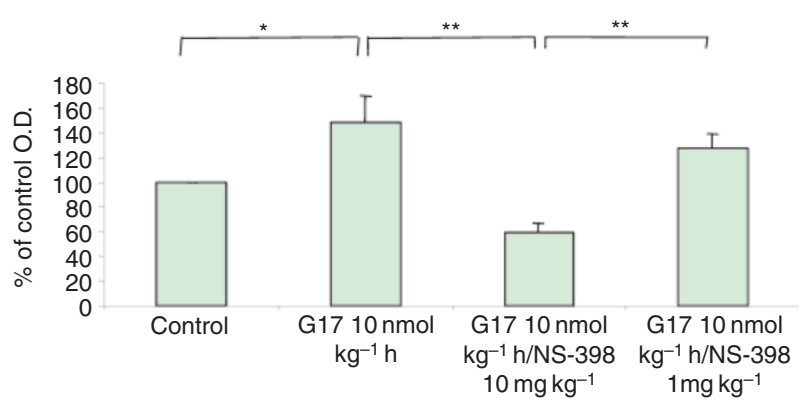

Figure 3 Western blot of cyclin DI expression. (A) in MC-26 colon cancer tissues treated with gastrin- $17\left(10 \mathrm{nmol} \mathrm{kg}{ }^{-1} \mathrm{~h}^{-1}\right)$ in the absence or presence of NS-398 (I and $\left.10 \mathrm{mg} \mathrm{kg}^{-1}\right)$. (B) Analysis of Western blot densitometry. $* P<0.05$, $* * P<0.01$. 
and weight from control was detected in mice treated with both NS-398 $\left(1 \mathrm{mg} \mathrm{kg}^{-1}\right)$ and G-17 $\left(10 \mathrm{nmol} \mathrm{kg}{ }^{-1} \mathrm{~h}^{-1}\right)$. Moreover, tumour growth stimulated by G-17 was reversed by both low$\left(1 \mathrm{mg} \mathrm{kg}^{-1}\right)$ and high-dose $\left(10 \mathrm{mg} \mathrm{kg}^{-1}\right) \mathrm{NS}-398$. The latter not only suppressed gastrin-induced tumour growth, but also unstimulated (control) tumour growth (tumour volume: 955.8 \pm 325.1 $\mathrm{mm}^{3}$ vs $1220.2 \pm 224.0 \mathrm{~mm}^{3}, \quad P<0.05$; tumour weight: $0.15 \pm 0.09 \mathrm{~g}$ vs $0.38 \pm 0.07 \mathrm{~g}, P<0.01)$.

Consistent with tumour growth, cyclin D1 protein and PCNA index in tumour tissues were significantly greater in the tumour tissue of G-17 treated mice. Low-dose NS-398 $\left(1 \mathrm{mg} \mathrm{kg}^{-1}\right)$ partially attenuated gastrin-induced cyclin D1 and PCNA, while high-dose NS-398 $\left(10 \mathrm{mg} \mathrm{kg}^{-1}\right)$ significantly decreased both of them to values significantly less than unstimulated conditions (Figures 3 and 4).

\section{COX-2 promoter activity, COX-2 protein expression and prostaglandin $\mathrm{E}_{2}\left(\mathrm{PGE}_{2}\right)$ levels}

To study whether G-17 is capable of inducing COX-2 transcription, cells were transiently transfected with a COX-2 promoter luciferase

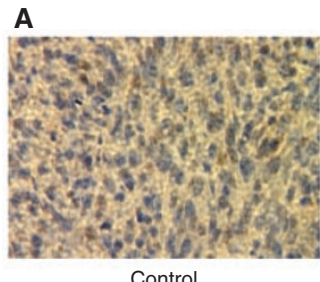

Control

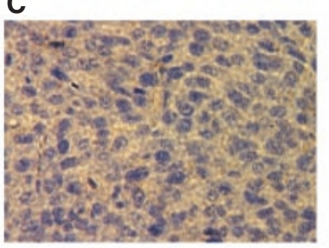

G17 $10 \mathrm{nmol} \mathrm{kg}^{-1} \mathrm{~h}^{-1}$ NS-398 $10 \mathrm{mg} \mathrm{kg}^{-1}$

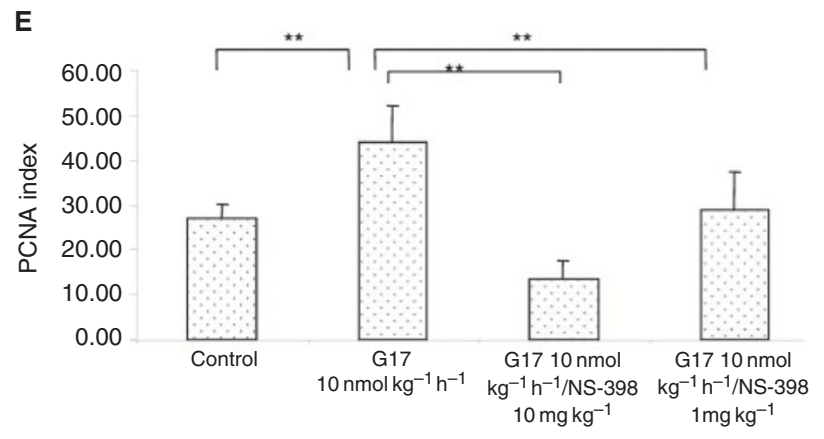

Figure 4 Proliferating cell nuclear antigen (PCNA) in colon cancer treated with gastrin- 17 in the absence or presence of NS-398. Cells were injected subcutaneously in the flank of 6 to 10 -week old male BALB/c mice. Mice were sacrificed on day 18 , and PCNA index was determined by immunohistochemistry, as described in the Materials and Methods section (A: Control, B: Gastrin- $1710 \mathrm{nmol} \mathrm{kg}{ }^{-1} \mathrm{~h}^{-1}, \mathbf{C}$ : Gastrin- $1710 \mathrm{nmol}$ $\mathrm{kg}^{-1} \mathrm{~h}^{-1}$ and NS-398 $10 \mathrm{mg} \mathrm{kg}^{-1}$, D: Gastrin-17 $10 \mathrm{nmol} \mathrm{kg}^{-1} \mathrm{~h}^{-1}$ and NS-398 $1 \mathrm{mg} \mathrm{kg}^{-1}$, E: Quantification of PCNA index. ${ }^{*} P<0.05$, ** $P<0.01)$. construct, and luciferase assays were performed, as described above. COX-2 promoter activity was induced approximately two-fold in transfected cells incubated in presence of G-17 (100 nM) at $24 \mathrm{~h}$. In addition, COX-2 protein expression was significantly increased in MC-26 cells incubated in the presence 10, 20, 50 and $100 \mathrm{nM} \mathrm{G}-17$ at $24 \mathrm{~h}$. When cells were incubated with $20 \mathrm{nM} \mathrm{G}-17$, levels of $\mathrm{PGE}_{2}$, the major product of cyclo-oxygenase, were significantly increased at $24 \mathrm{~h}\left(215.9 \pm 13.6 \mathrm{pg}^{-1}\right.$ well $^{-1}$ vs $170.8 \pm 27.9 \mathrm{pg}^{-1} \mathrm{well}^{-1}$, $P<0.05)$ and $48 \mathrm{~h}\left(350.8 \pm 39.7\right.$ pg well $^{-1}$ vs $272.2 \pm 35.6$ pg well $^{-1}$, $P<0.05)$ (Figure 5).

\section{DISCUSSION}

Previous studies have reported that gastrin and NSAIDs possess opposing effects on cell proliferation. Gastrin has long been recognized as a mitogenic factor that stimulates the growth of preexisting tumours of GI origin (Baldwin and Shulkes, 1998; Smith and Watson, 2000; Dockray et al, 2001). Interruption of the effects of gastrin as a potential target in the treatment of colorectal cancer, using several different approaches, such as the gastrin (CCK-B or CCK-2) receptor antagonists, proglumide and benotript, has been assessed (Watson et al, 1992a,b). The major drawback of these compounds is their lack of potency, with relatively high concentrations required to displace amidated G-17. L-365,260 has a greater affinity for the gastrin receptor than proglumide and has been shown to reverse gastrin-stimulated growth of GI tumour cell, both in vitro and in vivo (Piontek and Hengels, 1993; Watson et al, 1991). However, this antagonist does not appear to inhibit basal

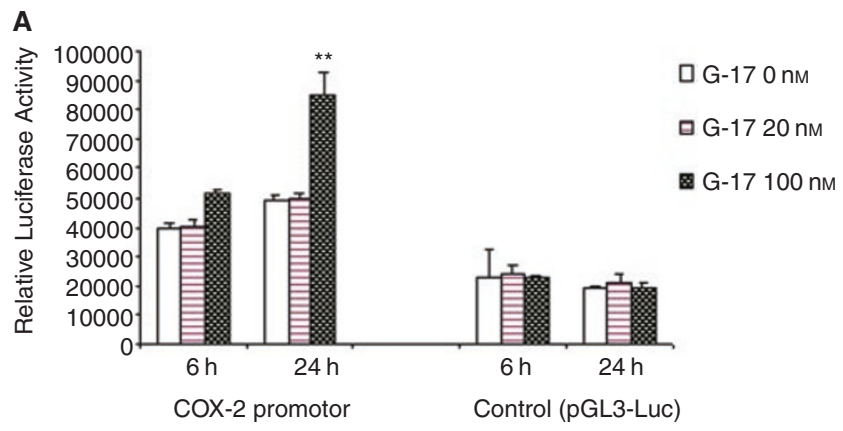

B

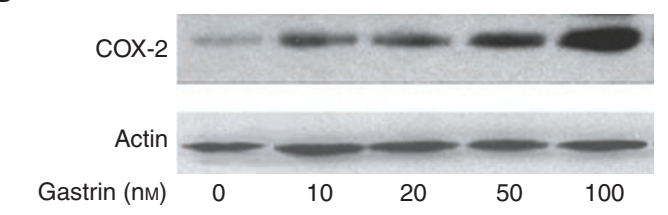

C

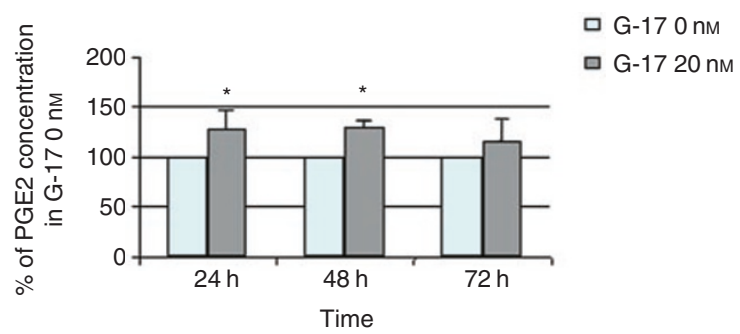

Figure 5 COX-2 promoter activity, COX-2 protein and prostaglandin synthesis induced by gastrin- 17. (A) COX-2 promoter activity, (B) protein expression, and $(\mathbf{C})$ change of prostaglandin levels in MC-26 cells in response to gastrin. $* P<0.05$, $* * P<0.01$. 
growth of the tumour and lacks the capacity to interact with alternate gastrin receptor subtypes. In contrast, the effectiveness of antigastrin antibodies in inhibiting tumour growth has been demonstrated in several animal models of colorectal cancer (Watson et al, 1995, 1996, 2000).

The benefit of nonselective COX inhibitors in preventing tumorigenesis and tumour growth has been demonstrated in numerous studies (DuBois and Smalley, 1996; Levy, 1997). However, the use of these agents is often associated with the development of serious adverse GI events. COX-2 selective inhibitors are thought to exert similar anti-inflammatory and antimitogenic effects, but with diminished toxicity (Wolfe et al, 1999). N-[2-(cyclohexyloxy)-4-nitrophenyl]-methanesulphonamide (NS-398) is a sulfonamide derivative that inhibits COX-2 specifically with an $\mathrm{IC}_{50}$ of $30 \mathrm{nM}$. It does not affect COX-1 enzyme activity at concentrations exceeding $100 \mu \mathrm{M}$, and it inhibits COX-1 dependent prostanoid production only minimally even at doses $>200 \mathrm{mg} \mathrm{kg}^{-1}$ (Futaki et al, 1994; Gierse et al, 1995). The results of these studies suggest the possibility of a functional relationship between gastrin and COX-2 expression and demonstrate that COX-2 selective inhibition is capable of reversing the trophic properties of growth on colorectal adenocarcinoma. Because COX-2 selective inhibition has been shown to possess antineoplastic properties with few adverse GI events, the use of these agents may potentially represent a novel therapeutic approach to reduce the risk of colon cancer associated with hypergastrinaemia.

Despite these observations, the cellular and molecular mechanisms governing any potential relationship between COX-2 and gastrin require further clarification. In this study, when MC-26 colorectal cancer cells were incubated in the presence of gastrin, significant increases in COX-2 protein levels and COX-2 promoter activity was detected, compared with control conditions. Furthermore, using a sensitive enzyme immonoassay (EIA) for the measurement of $\mathrm{PGE}_{2}$, modest, but significant, increases in $\mathrm{PGE}_{2}$ levels in response to $20 \mathrm{nM}$ gastrin were observed. While further studies are necessary to clarify any possible functional relationship, the present results do imply that a COX-2 mediated pathway may be stimulated by gastrin and may contribute to its trophic effects on colorectal cancer.

Cyclin D1 is a protein involved in cell cycle regulation in both normal and neoplastic cells (Hunter and Pines, 1994). In the G1 (resting) phase of the cell cycle, cyclin D1 along with its cyclin dependent kinase (CDK) partner, is responsible for transition to the S (DNA synthesis) phase (Sherr, 1996). Overexpression of cyclin D1 releases a cell from its normal control and causes transformation to a malignant phenotype. Previous studies have demonstrated that cyclin D1 is increased in adenomatous polyps and in both sporadic and familial forms of colorectal cancer (Motokura and Arnold, 1993; Bartkova et al, 1994; Arber et al, 1996, 1997). Consistent with these prior observations, in the present study, gastrin increased cyclin D1 levels in vivo and in vitro, an effect that was reversed with NS-398. In addition to cyclin D1, PCNA functions as an auxiliary protein to DNA polymerase gamma and as a co-factor in DNA synthesis. The synthesis and expression of PCNA are enhanced in proliferating cells including those that are tumour-derived. Determination of PCNA represents one of the most reliable methods for evaluating proliferation in cells and tissues (Prosperi, 1997). In the present study, the PCNA index was significantly increased in gastrin-treated tumours when compared with control. Moreover, similar to studies assessing cyclin D1, the addition of NS-398 (10 mg kg-1 body weight) reversed the gastrin-induced increase in PCNA expression.

In conclusion, the results of these studies demonstrate that COX-2 might represent one of the downstream targets of gastrin and that selective COX-2 inhibition is capable of reversing the trophic properties of gastrin and presumably prevent growth of CRC induced by hypergastrinaemia. In addition to its effects on cyclin D1 and PCNA, it is certainly possible that other intracellular pathways are involved in mediating the trophic properties of gastrin on neoplastic proliferation. Although the therapeutic implications are obvious, further studies will be necessary to elucidate the cellular and molecular mechanisms governing any potential functional relationship between COX-2 and gastrin.

\section{REFERENCES}

Arber N, Doki Y, Han EK, Sgambato A, Zhou P, Kim NH, Delohery T, Klein MG, Holt PR, Weinstein IB (1997) Antisense to cyclin D1 inhibits the growth and tumorigenicity of human colon cancer cells. Cancer Res 57: $1569-1574$

Arber N, Hibshoosh H, Moss SF, Sutter T, Zhang Y, Begg M, Wang S, Weinstein IB, Holt PR (1996) Increased expression of cyclin D1 is an early event in multistage colorectal carcinogenesis. Gastroenterology 110: 669-674

Baldwin GS, Shulkes A (1998) Gastrin, gastrin receptors and colorectal carcinoma. Gut 42: $581-584$

Barnes CJ, Cameron IL, Hardman WE, Lee M (1998) Non-steroidol antiinflammatory drug effect on crypt cell proliferation and apoptosis during initiation of rat colon carcinogenesis. Br J Cancer 77: 573-580

Barnes CJ, Lee M (1998) Chemoprevention of spontaneous intestinal adenomas in the adenomatous polyposis coli Min mouse model with aspirin. Gastroenterology 114: 873-877

Bartkova J, Lukas J, Strauss M, Bartek J (1994) The PRAD-1/cyclin D1 oncogene product accumulates aberrantly in a subset of colorectal carcinomas. Int J Cancer 58: $568-573$

Dockray GJ, Varro A, Dimaline R, Wang T (2001) The gastrins: their production and biological activities. Annu Rev Physiol 63: 119-139

DuBois RN, Smalley WE (1996) Cyclooxygenase, NSAIDs, and colorectal cancer. J Gastroenterol 31: 898-906

Futaki N, Takahashi S, Yokoyama M, Arai I, Higuchi S, Otomo S (1994) NS398 , a new anti-inflammatory agent, selectively inhibits prostaglandin $\mathrm{G} / \mathrm{H}$ synthase/cyclooxygenase (COX-2) activity in vitro. Prostaglandins 47: 55 59

Giardiello FM, Offerhaus GJ, DuBois RN (1995) The role of nonsteroidal anti-inflammatory drugs in colorectal cancer prevention. Eur J Cancer 31A: $1071-1076$

Gierse JK, Hauser SD, Creely DP, Koboldt C, Rangwala SH, Isakson PC, Seibert K (1995) Expression and selective inhibition of the constitutive and inducible forms of human cyclo-oxygenase. Biochem J 305: 479-484

Giovannucci E, Rimm EB, Stampfer MJ, Colditz GA, Ascherio A, Willett WC (1994) Aspirin use and the risk for colorectal cancer and adenoma in male health professionals. Ann Intern Med 121: $241-246$

Hakanson R, Blom H, Carlsson E, Larsson H, Ryberg B, Sundler F (1986) Hypergastrinaemia produces trophic effects in stomach but not in pancreas and intestines. Regul Pept 13: 225-233

Hunter T, Pines J (1994) Cyclins and cancer. II: Cyclin D and CDK inhibitors come of age. Cell 79: $573-582$

Klingensmith ME, Neville LJ, Delpire E, Wolfe MM, Soybel DI (1999) Gastrin-mediated effects of omeprazole on rat colon mucosa. Surgery 126: $272-278$

Koh TJ, Chen D (2000) Gastrin as a growth factor in the gastrointestinal tract. Regul Pept 93: 37-44

Koh TJ, Dockray GJ, Varro A, Cahill RJ, Dangler CA, Fox JG, Wang TC (1999) Overexpression of glycine-extended gastrin in transgenic mice results in increased colonic proliferation. J Clin Invest 103: 1119-1126

Lamberts R, Wartenberg T, Creutzfeldt W (1999) Role of circulating gastrin in colorectal adenomas and carcinomas. Digestion 60: $101-109$

Levy GN (1997) Prostaglandin H synthases, nonsteroidal anti-inflammatory drugs, and colon cancer. Faseb J 11: 234-247

Modlin IM, Kidd M, Marks IN, Tang LH (1997) The pivotal role of John S. Edkins in the discovery of gastrin. World J Surg 21: 226-234

Motokura T, Arnold A (1993) Cyclin D and oncogenesis. Curr Opin Genet Dev 3: $5-10$ 
Piontek MK, Hengels KJ (1993) Differential mode of action of high- and lowaffinity CCK/gastrin receptor antagonists in growth inhibition of gastrinresponsive human gastric adenocarcinoma cells in vitro. Anticancer Res 13: $715-720$

Prosperi E (1997) Multiple roles of the proliferating cell nuclear antigen: DNA replication, repair and cell cycle control. Prog Cell Cycle Res 3: $193-210$

Sawaoka H, Kawano S, Tsuji S, Tsujii M, Gunawan ES, Takei Y, Nagano K, Hori M (1998) Cyclooxygenase-2 inhibitors suppress the growth of gastric cancer xenografts via induction of apoptosis in nude mice. Am J Physiol 274: G1061-G1067

Sheng H, Shao J, Kirkland SC, Isakson P, Coffey RJ, Morrow J, Beauchamp RD, DuBois RN (1997) Inhibition of human colon cancer cell growth by selective inhibition of cyclooxygenase-2. J Clin Invest 99: 2254-2259

Sherr CJ (1996) Cancer cell cycles. Science 274: $1672-1677$

Singh P, Velasco M, Given R, Wargovich M, Varro A, Wang TC (2000) Mice overexpressing progastrin are predisposed for developing aberrant colonic crypt foci in response to AOM. Am J Physiol Gastrointest Liver Physiol 278: G390-G399

Singh P, Walker JP, Townsend Jr CM, Thompson JC (1986) Role of gastrin and gastrin receptors on the growth of a transplantable mouse colon carcinoma (MC-26) in BALB/c mice. Cancer Res 46: 1612-1616

Smith AM, Watson SA (2000) Review article: gastrin and colorectal cancer. Aliment Pharmacol Ther 14: $1231-1247$

Stepan VM, Sawada M, Todisco A, Dickinson CJ (1999) Glycine-extended gastrin exerts growth-promoting effects on human colon cancer cells. Mol Med 5: $147-159$

Sundler F, Hakanson R, Carlsson E, Larsson H, Mattsson H (1986) Hypergastrinemia after blockade of acid secretion in the rat: trophic effects. Digestion 35: 56-69

Thorburn CM, Friedman GD, Dickinson CJ, Vogelman JH, Orentreich N, Parsonnet J (1998) Gastrin and colorectal cancer: a prospective study. Gastroenterology 115: 275-280

Tsujii M, Kawano S, Tsuji S, Sawaoka H, Hori M, DuBois RN (1998) Cyclooxygenase regulates angiogenesis induced by colon cancer cells. Cell 93: $705-716$
Watson S, Durrant L, Elston P, Morris D (1991) Inhibitory effects of the gastrin receptor antagonist (L-365,260) on gastrointestinal tumor cells. Cancer 68: $1255-1260$

Watson SA, Clarke PA, Morris TM, Caplin ME (2000) Antiserum raised against an epitope of the cholecystokinin $\mathrm{B} /$ gastrin receptor inhibits hepatic invasion of a human colon tumor. Cancer Res 60: 5902-5907

Watson SA, Crosbee DM, Morris DL, Robertson JF, Makovec F, Rovati LC, Hardcastle JD (1992a) Therapeutic effect of the gastrin receptor antagonist, CR2093 on gastrointestinal tumour cell growth. Br J Cancer 65: $879-883$

Watson SA, Michaeli D, Grimes S, Morris TM, Crosbee D, Wilkinson M, Robinson G, Robertson JF, Steele RJ, Hardcastle JD (1995) Anti-gastrin antibodies raised by gastrimmune inhibit growth of the human colorectal tumour AP5. Int J Cancer 61: 233-240

Watson SA, Michaeli D, Grimes S, Morris TM, Robinson G, Varro A, Justin TA, Hardcastle JD (1996) Gastrimmune raises antibodies that neutralize amidated and glycine- extended gastrin-17 and inhibit the growth of colon cancer. Cancer Res 56: $880-885$

Watson SA, Morris DL, Durrant LG, Robertson JF, Hardcastle JD (1992b) Inhibition of gastrin-stimulated growth of gastrointestinal tumour cells by octreotide and the gastrin/cholecystokinin receptor antagonists, proglumide and lorglumide. Eur J Cancer 28A(8-9): 1462 - 1467

Watson SA, Smith AM (2001) Hypergastrinemia promotes adenoma progression in the APC(Min-/+) mouse model of familial adenomatous polyposis. Cancer Res 61: 625-631

Wolfe MM (1992) Hypergastrinemia and colonic neoplasia: coincidental or related?. Gastroenterology 103: $1361-1363$

Wolfe MM, Lichtenstein DR, Singh G (1999) Gastrointestinal toxicity of nonsteroidal antiinflammatory drugs. N Engl J Med 340: 1888-1899

Workman P, Twentyman P, Balkwill F, Balmain A, Chaplin D, Double J, Embleton J, Newell D, Raymond R, Stables J, Stephens T, Wallace J (1998) United Kingdom Co-ordinating Committee on Cancer Research (UKCCCR) Guidelines for the welfare of animals in experimental neoplasia, 2nd edn. Br J Cancer 77: 1-10 